\title{
Comparative-Analysis Based Study of Synonymous Relational Adjectives in Tatar and English
}

\author{
Venera Khisamova \\ Lyutsiya Khismatullina
}

\begin{abstract}
Kazan (Volga Region) Federal University, Institute of International Relations, History and Oriental Studies, Russian Federation
\end{abstract} Email: lutikg@yandex.ru, leila68@yandex.ru

Doi:10.5901/mjss.2015.v6n3s2p394

\begin{abstract}
This research was conducted to demonstrate the denotational similarity and differences of the Tatar synonymous relational adjectives and their English counterparts. It helped to depict all the nuances of the meanings expressed by synonyms and may help to solve the difficulty of choosing the appropriate word in the communication discourse. The research deals with the Tatar relational adjectives related to the notions of place, time, activity and occupation and their English counterparts. In the article we disagree with the opinion widely stated in Tatar linguistic literature and textbooks that due to their referential character relational adjectives can hardly synonymize. The findings revealed that 69 Tatar relational adjectives may be organized into synonymic rows. Though Tatar and English are non-related languages, the comparative analysis demonstrated the fact that the synonymic rows denote similar denotations either as lexico-semantic unities or as separate lexical items; the differences may represent the culture-connected peculiarities.
\end{abstract}

Keywords: semantics, synonymy, synonymic row, relational adjectives, comparative study.

\section{Introduction}

Synonyms are one of the most important indicators of any language existence and development. The attention paid to them in the process of learning is essential and undoubtedly right as the knowledge of synonyms leads both to the comprehension of a startling variety of colors and stylistic nuances of synonyms and the appropriate choice of the correct one in the language discourse. The latter one presents many pitfalls for English-language learners, as choosing the word, that precisely conveys the desired meaning and avoids unwanted implications, could be really difficult.

Synonymy represents peculiar semantic relationships that have been treated differently if not critically and restrictively by different scientists at different times. Both in English and Tatar linguistics there are definitions of synonyms as two or more words denoting the same notion (Ullman, 1984; Apresyan, 1995); similar in meaning (Murphy, 2003), belonging to the same part of speech (Safiullina, 1999); partially interchangeable (Antrushina, 2001); possessing identical collocational behavior (Khomenko, 2006). Hence, one of the main problems in studies of synonymy is to find out the objective criteria for organizing lexical items into a synonymic row so that the results would be included into monolingual or bilingual dictionaries of synonyms (Khismatullina, 2009).

In English there is abundant research on lexical synonymy, dictionaries and thesauruses have been compiled for educational and professional purposes. In Tatar such research works are carried out rarely for their being meticulous and time-consuming. Moreover, there are none of them devoted to a specific part of speech; the group of relational adjectives being the one that has received unfairly little attention. It is caused by debates about the synonymizing of the relational adjectives. They are considered to be "restricted in meaning". F.Khisamova points out, that the difference between attributive and relational adjectives is that relational adjectives do not denote the property directly, but are related to the semantic structure of the motivational word (Khisamova 2006). These relations include a reference to the name of the object, featured by a complex unity of typical and constant elements forming the property, indicating the potential polysemy of the relational adjectives.

What is needed is a comprehensive investigation into the fine-grained semantic structure and practical implications of the relational adjectives in Tatar that would prove their lexico-semantic status and synonymizing capacity. Another reason is that it would greatly benefit the language learners or translators and would be a definite improvement over their choice of the correct word in English. For this purpose, in this article we present the Tatar relational adjectives compared with their English counterparts. 
In his article Fortesque points out, one possible approach is to focus on the empirical data presented by the languages compared, hopefully "triangulating" in inductively on the common parameters that can subsequently be taken to be semantically universal (Fortesque, 2010). In Tatar linguistics the approach was initially developed by Gatiatullina Z.Z. (Gatiatullina, 1982), Bakeyeva D.H. (Bakeyeva, 1985), Zakamullina M.N. (Zakamullina,1999), Khisamova V.N. (Khisamova, 2004), which was successfully introduced into language teaching practice in Tatar State Institute of Humanities (between the years 1995-2005) where the student body basically consisted of the Tatars. We strongly support the approach and believe, that such research will make it possible to reveal denotational similarity and differences of the synonyms within one notional scale in different languages; deeper understand the semantic and functional variety of the relational adjectives in Tatar and their counterparts in English; consequently, contribute to making a bilingual (Tatar-English) Dictionary of Synonyms.

\section{Method}

The present study is an endeavor in that the research question is answered by comparing and contrasting the relational adjectives in Tatar and their counterparts in English. During the first phase of the study in order to collect a substantial body of data, the Tatar dictionary of synonyms Sinonimnar Suzlege by Hanbikova and Safiullina (1999) was examined in Tatar. The English synonyms were collected from Oxford Learner's Thesaurus: A Dictionary of Synonyms (2012), Oxford Dictionary of Synonyms and Antonyms (1999), New Webster's Dictionary and Thesaurus (1995).

Secondly, the selected lexical items were semantically and functionally analyzed. Relying crucially on the granularity of meaning and the specificity of representation, the synonymous lexical items were considered in the written discourse. The literature corpus comprised with the newspaper corpus consisted altogether of 136 Tatar and 367 English statements and quotes. Based on the context-dependent implication of the synonymous lexical items, we expanded some of the Tatar synonymic rows.

The Tatar relational adjectives and their English equivalents in the aforementioned dictionaries and research corpora were picked out manually. Based on the traditional approach, the Tatar relational adjectives and their English equivalents were categorized into three groups:

the relational adjectives denoting place;

the relational adjectives denoting time;

the relational adjectives denoting activity and occupation.

Finally, the relational adjectives were examined in the light of comparative analysis. As we focus our attention on synonymy as sense-synonymy and lexeme-synonymy, the Tatar and English monolingual glossaries were examined. The valid data was collected from the Tatar monolingual glossaries Tatar Teleneng An'latmaly Suzlege (vol.1-3, 1977-1981), Tatar Teleneng An'latmaly Suzlege (Ganiyev, 2005) and the English monolingual glossaries Longman Exams Dictionary (2006), Longman Dictionary of Contemporary English (2009) and Merriam-Webster Online Dictionary. The definitionbased sense analysis of the synonyms helped us determine the most appropriate choice of the equivalent word in English.

\section{Analysis}

In our research we call synonymous relational adjectives two or more lexical units, denoting the same notion and sharing at least one common semantic property, but different in emotional coloring and stylistic characteristics, intersubstitutable in some contexts, "as context is a dynamic construct that appears in different formats in language use both as a repository and trigger of knowledge" (Kecskes, 2008).

As previously mentioned, our research is based on the traditional classification of the relational adjectives in Tatar denoting place, time, activity and occupation; although in English they are generally presented by two types of adjectives: the ones denoting property through relation to time and place are called "relational" adjectives, the others are called "topical".

In what follows an attempt is made to explain the semantic properties of the synonymous relational adjectives; demonstrate the similarities and differences between the Tatar synonyms and their English counterparts; cross-tabulate the examined data.

\subsection{Tatar synonymous relational adjectives denoting time vs English counterparts}

'Time' is one of the main objective forms of the existence of a developing matter, which is measured as certain moments, 
periods, and, from a subjective point of view, all existing tangible and intangible objects possess such characteristics as the beginning, the duration and the end.

The research showed that the group of synonymous relational adjectives related to time can be made of such Tatar lexical items as boryngy, wakytly, wakytsyz, bashlangych, songy, teshke and their English counterparts ancient, temporary, initial, last, untimely, midday. The adjectives express different relations to time and time properties: boryngy /ancient are related to the distant past, wakytly / temporary to temporality, bashlangych / initial to the starting point of something, songy / last to termination, wakytsyz / untimely to the events that happened before an expected time, teshke I midday to what is happening in the middle of the day.

Examining and comparing the synonymic rows we found out that the Tatar wakytsyz is synonymous with wakytynnan elek, wakytynnan alda, ketmegende, while the English untimely does not have any synonyms fixed in dictionaries as a dominant word. According to the semantic representation and the collocational behavior untimely expresses the nuances peculiar to Tatar wakytynnan alda, wakytsyz (the untimely end - wakytynnan alda betu, the untimely death - wakytsyz ulem). Yet, the Tatar synonyms are semantically identical with the English adjectives early and unexpected, which, consequently, let us expand the synonymic row wakytsyz by adding one more lexical item irte (early rains - irte yanggyrlar; the early arrivial - wakytynnan alda kilu; the unexpected outburst of laughter-ketmegende kelep zhiberu)

Similar is the case of Tatar synonymic row teshke and its English counterpart midday which as an adjective does not have any synonyms.

The Tatar synonymic row songy and the English last are related to the time preceding present (songy ellarny - for the last three decades, songy heberler - the latest news) or denoting the phenomenon, coming after all others in time (songy tramvay - the last tram). Moreover, both synonymic rows may denote the idea that cannot be altered (songy suzne eytu; ahyrgy ant; the final decision); the highest degree or rank (aktyk tamchy kanga chakly sugyshu; catch the last straw), unsuitable or least wanted person (aktyk keshe; the last person they would have invited). In addition, the English synonyms differ from the Tatar synonymic row by expressing the idea of 'coming near the end of speech, event or activity' (the concluding words, the conclusive speech) and 'leading gradually to death' (a terminal disease), both implying the indirect reference to time.

The Tatar synonymic row boryngy and the English ancient express two sets of meaning: 1) 'belonging to a time long ago' and 2) 'having existed for a long time'. The first is conveyed in Tatar by the dominant word boryngy (boryngy zaman, boryngy urmannar, boryngy zhamgiyat), whereas in English the meaning is expressed by the synonymous adjectives bygone, earlier, immemorial, olden, past, prehistoric, primeval, primitive, primordial, remote (a bygone age, time immemorial, remote time, an antique plate, primeval forests). The second meaning is equally expressed by the synonymic rows in both languages (kadimi yazu - the ancient art of calligraphy, borynnan kalgan yola - antiquated device, iskergen kanunnar - obsolete equipment, iske kiyem - old-fashioned clothes), though the Tatar boryngy does not convey the nuance.

As for the Tatar wakytly and its synonym az wakytly that carry the implication of 'lasting for only a limited time' or 'intended to be used for only a period of time', they share almost all the senses expressed by the English synonymic row temporary (wakytly chara - a temporary measure, wakytly eshche - a transient worker, az wakytly behet - short-lived happiness, wakytly pauza - a momentary pause). Similar is the pair of the Tatar bashlangych and the English initial, that denote the relation to the beginning (berenche adym - the initial step, bashlangych nokta - the starting point) or reveal the things existing or happening first (bashlangych mektep - the primary school, berenche class - the first victory, ing berenche karlar - the earliest birds, berenche kul'yazma - the original version).

Table 1 shows the Tatar synonymous relational adjectives with their English counterparts related to time. The context-determined synonyms are given in italics. 
Table 1: Tatar synonymous relational adjectives denoting time and their English counterparts

\begin{tabular}{|c|c|c|c|c|}
\hline \multicolumn{2}{|c|}{$\begin{array}{l}\text { Tatar synonymic row } \\
\text { dominant word }\end{array}$} & \multirow{2}{*}{\begin{tabular}{|l} 
Meaning \\
belonging to a time long ago
\end{tabular}} & \multirow{2}{*}{\begin{tabular}{|l} 
Tatar synonyms \\
boryngy
\end{tabular}} & \multirow{2}{*}{\begin{tabular}{|l|} 
English counterparts \\
ancient, bygone, earlier, immemorial, olden, \\
past, prehistoric, primeval, primitive, primordial, \\
remote
\end{tabular}} \\
\hline 1 & boryngy & & & \\
\hline & & \multirow{3}{*}{ having existed for a long time } & iskergen & old-fashioned \\
\hline & & & $\begin{array}{l}\text { kadimi, borynnan } \\
\text { kalgan, }\end{array}$ & ancient, antiquated \\
\hline & & & iske & obsolete \\
\hline 2 & teshke & $\begin{array}{l}\text { happening in the middle of the } \\
\text { day }\end{array}$ & $\begin{array}{l}\text { teshke, } \\
\text { tesh wakytyndagy, } \\
\text { kendezge, } \\
\text { ken urtasyndagy, ken } \\
\text { uzegendege } \\
\end{array}$ & midday \\
\hline \multirow[t]{3}{*}{3} & \multirow[t]{3}{*}{ wakytly } & \multirow{2}{*}{ lasting for only a limited time } & wakytly & temporary , momentary \\
\hline & & & az wakytly & short-lived, short-term \\
\hline & & used for only a period of time & wakytly & temporary, transient \\
\hline \multirow[t]{3}{*}{4} & \multirow[t]{3}{*}{ bashlangych } & related to the beginning & bashlangych & initial, primary \\
\hline & & \multirow{2}{*}{ existing or happening first } & berenche & first \\
\hline & & & ing berenche & earliest, original \\
\hline \multirow[t]{2}{*}{5} & \multirow[t]{2}{*}{ songy } & coming after all others in time & songy, aktyk, ahyrgy & last \\
\hline & & $\begin{array}{l}\text { Coming near the end of speech, } \\
\text { event or activity }\end{array}$ & aktyk, ahyrgy & concluding, conclusive \\
\hline \multirow[t]{3}{*}{6} & \multirow[t]{3}{*}{ wakytsyz } & \multirow{3}{*}{ happening before expected time } & $\begin{array}{l}\text { wakytynnan elek, } \\
\text { wakytynnan alda }\end{array}$ & untimely \\
\hline & & & ketmegende & unexpected \\
\hline & & & irte & early \\
\hline
\end{tabular}

\subsection{Tatar synonymous relational adjectives denoting place vs English counterparts}

Generally, by the notion of 'place' we understand the space that can be occupied by someone or something, where something is or may be located. While speaking of specific objects, 'place' is also understood as a certain part, a separate fragment, a piece of land on the surface of the Earth.

In the semantic structures of the Tatar synonymic rows algy, asky, argy, tyshky, echke, yugarygy and their English counterparts front, lower, distant, external, internal, upper the relation to place is conveyed by expressing the ideas of 'remaining in a place', 'located at different distances and positions'.

The location of things out of sight or far away is determined by the Tatar argy, yeraktagy, ikenche, tege. The meaning is vividly expressed by the first two synonyms: argy yaktan bolyt kile (the thunderstorm is coming from afar), yeraktagy yoldyz yaktyrak yana (a distant star shines brighter), whereas the latter two are more likely to denote the objects located on another place (ikenche urynda/in another place), on the opposite side (yulnyn ikenche yagyna chyk!/go to the other side of the road) or at the other end (tege ochta/at the other end). In comparison, the English synonymic row conveys the location far away in space emphasizing this or that feature of a place stronger: inaccessible is frequently applied to objects capable of being reached only with great difficulty or not being reached at all, remote, out-of-the-way denote the location of the objects from populous or much-traveled regions, outlying implies being at a distance far from the central part or the main body, god forsaken expressess the location far away from where people live, because it contains nothing interesting and cheerful. The relation to location on another place or the other side is denoted by the English other and opposing which are not synonymous with distant.

The Tatar synonymous relational adjectives tyshky and oske are similar to the English synonymous adjectives outer, outward, external, outside, exterior, which denote the location on the outside of something. Though small in number, the Tatar synonymic row denotes approximately all the senses the English synonyms have (tyshky kuyafet - the outward appearance, tyshky donya - outside/external world; eske kiyem - outer clothing/ overcoat, eske kat buyay - the exterior wall paint).

The other Tatar synonymic rows denote the location of objects under beneath (asky), inward (echke), at the top or highest part (yugarygy), in the front (algy). The notions are denoted in English by the lexical items not synonymous with 
each other (asky iren - lower lip, asky/ tubenge kat - the ground floor; echke bulme - the inner room, echke organnar the internal organs, echten kiya torgan kiyem - the underclothes; yugarygy och - the upper part (of the village), estege paluba - the upper deck, estege tartma - the top drawer; algy ishek - the front door, aldagy saflar - front-line troops).

Table 2 depicts the Tatar synonymous relational adjectives with their English counterparts related to place. The context-determined synonyms are given in italics.

Table 2: Tatar synonymous relational adjectives denoting place and their English counterparts

\begin{tabular}{|c|c|c|c|c|}
\hline \multicolumn{2}{|c|}{$\begin{array}{l}\text { Tatar synonymic row } \\
\text { dominant word }\end{array}$} & Meaning & Tatar synonyms & English counterparts \\
\hline \multirow[t]{2}{*}{1} & \multirow[t]{2}{*}{ algy } & \multirow[t]{2}{*}{ located in or at the front of something } & algy, al, aldagy & front, anterior \\
\hline & & & algy, aldagy & forward \\
\hline 2 & asky & $\begin{array}{l}\text { positioned below the other things or of } \\
\text { the bottom part of something }\end{array}$ & asky, tubendege & lower, ground \\
\hline \multirow[t]{3}{*}{3} & \multirow[t]{3}{*}{ argy } & being at a great distance & argy, yeraktagy & $\begin{array}{l}\text { distant, far, far } \\
\text { away, remote }\end{array}$ \\
\hline & & being in a position on the other side & argy, ikenche, tege & opposite, other \\
\hline & & $\begin{array}{l}\text { located far from interesting people } \\
\text { and places; not at all interesting or } \\
\text { appealing }\end{array}$ & $\begin{array}{l}\text { zhehennem } \\
\text { astyndagy/tishegendege, alla } \\
\text { kargagan }\end{array}$ & god-forsaken \\
\hline \multirow[t]{2}{*}{4} & \multirow[t]{2}{*}{ tyshky } & \multirow[t]{2}{*}{$\begin{array}{l}\text { located, seen, or used on the outside } \\
\text { or surface of something }\end{array}$} & tyshky & $\begin{array}{l}\text { outward, external, } \\
\text { outside, outer, }\end{array}$ \\
\hline & & & oske & outer, exterior \\
\hline \multirow[t]{2}{*}{5} & \multirow[t]{2}{*}{ echke } & $\begin{array}{l}\text { located inside or toward the inside of } \\
\text { something }\end{array}$ & echke, echtege, & internal, inner \\
\hline & & located below or beneath something & $\begin{array}{l}\text { astan kiye torgan, echten kiye } \\
\text { torgan }\end{array}$ & underneath \\
\hline \multirow[t]{2}{*}{6} & \multirow[t]{2}{*}{ yugarygy } & $\begin{array}{l}\text { positioned at a higher position or level } \\
\text { than something else }\end{array}$ & $\begin{array}{l}\text { yugarygy, yugary, yugarydagy, } \\
\text { ostege }\end{array}$ & upper \\
\hline & & being the top part of something & oske & top \\
\hline
\end{tabular}

\subsection{Tatar synonymous relational adjectives denoting activity and occupation vs English counterparts}

Most Tatar adjectives related to activity and occupation are borrowed from the Arabic or Persian languages, which in the course of time actively interacted with other words in Tatar and created synonymous bonds with them. Among them we can determine the synonymous groups of adjectives related to military, political, social, scientific and cultural spheres.

The relation to the military sphere or military activities is denoted by the Tatar synonymic row herbi and its English counterpart military that describe an object pertaining to the armed services, soldiers or the military (herbi kiyem, a military parade) and associated with affairs of war (herbi esirler, military operations). What makes the synonymic rows different is the fact that Tatar synonyms herbi - gaskeri, armiyede hezmet ituche, armiyeche generally imply belonging to the armed forces while the lexemes in the English synonymic row military are rather applicable to war or warfare. For instance, armed refers to people having or bearing weapons and use of them for purpose of securing, warranty or frightening (armed escorts, armed robbery); belligerent and fighting denote engagement in war and eagerness to fight (belligerent nations; a fighting field); warlike implies the feeling of hostility that leads to war (warlike preparations); martial expresses fitness for war (martial men).

The Tatar relational adjectives izhtymagiy, sotsial, zhemgiyawy denote the property through the relation to social organization, activity, order (izhtymagiy hereket, sotsial tormysh). The similar meaning is expressed in English by the adjective social that forms three units of synonyms based on the following senses: relating to the human society/public as an aggregate body or the quality of people's life (social institutions, the societal structure, civilized standards); involving people in general (social services, public libraries, communal facilities); forming groups with others of the same species or living together in colonies of the same kind (social/gregarious insects). Indeed, the nuances of the compared synonymous relational adjectives stem from the meanings of the root nouns. The Tatar zhemgiyat denotes a group of people, united by social relations of production at a certain historical period; the English society refers to a group of people living together in an organized way or a group of people sharing similar interests, ideas.

The synonymic rows seyesi in Tatar and political in English denote the property through the relation to politics, 
affairs of state (seyesi publitsistika, political leaders). Compared with the English synonymic row, the Tatar relational adjectives seyesi and politic are absolutely identical in meaning. The English synonymic row, wider in sense, describes different aspects or features of political structures and activities: administrative relates to administration (administrative duties), diplomatic implies the activity of managing the relationships between countries (a diplomatic visit), governmental carries the implication of the affairs or structure of government or politics or the state (governmental power), legislative denotes belonging to legislation, having the power to make laws (the Legislative Council), parliamentary relates to the Parliament as the supreme legislative power (Parliamentary approval).

The Tatar relational adjectives gyilmi and fenni are synonymous by being related to science, its principles and methods (gyilmi donya, fenni hezmet). In English the property related to science is denoted by the synonymic row scientific, thus, its synonyms differ by implying accuracy, extreme care, conformity to fact (meticulous, precise, exact, rigorous, thorough), accentuating on reason (rational) and order (orderly, systematic, methodical). Thus, the English synonymous lexical items do not only relate to science as accumulated and established knowledge which has been systematized and formulated; but indicate the characteristics of scientific research, data, analysis, experiments, that essentially differentiate it from the Tatar gyilmi.

The relation to the cultural sphere is denoted by the Tatar relational adjective medeni and its English counterpart cultural (medeni eshchenlek - cultural activities, medeni tormysh - cultural life). Additionally, both synonymic rows have senses which indicate other properties. The Tatar kul'turaly refers to well-educated people, behaving in a sensible way, polite, conforming to high moral standards (kul'turaly keshe). The English synonymic row may imply the appreciation of beauty or good taste (aesthetic), pretensions to superior learning (highbrow), the inclination to increase knowledge (educational, enlightening, enriching), refinement in taste and manner (civilized).

Table 3: Tatar synonymous relational adjectives denoting activity and occupation and their English counterparts

\begin{tabular}{|c|l|l|l|l|}
\hline \multicolumn{2}{|l|}{$\begin{array}{l}\text { Tatar synonymic } \\
\text { row dominant word }\end{array}$} & Meaning & Tatar synonyms & English counterparts \\
\hline 1 & \multirow{2}{*}{ herbi } & relating to the armed forces & herbi, gaskeri, & military, \\
\cline { 3 - 5 } & & having or bearing weapons & gaskeri & armed \\
\cline { 3 - 5 } & & fighting a war & herbi & belligerent, fighting \\
\cline { 3 - 5 } & serving in the armed forces & $\begin{array}{l}\text { armiyede hezmet ituche, } \\
\text { armiyeche }\end{array}$ & enlisted, uniformed \\
\hline 2 & \multirow{2}{*}{ izhtymagiy } & $\begin{array}{l}\text { relating to society and living together in } \\
\text { an organized way }\end{array}$ & $\begin{array}{l}\text { izhtymagiy, sotsial, } \\
\text { zhemgiyawy }\end{array}$ & $\begin{array}{l}\text { social, communal, } \\
\text { organized, civilized }\end{array}$ \\
\cline { 3 - 5 } & & relating to people in general & zhemgiyawy & public \\
\hline 3 & seyesi & relating to politics & seyesi, politic & political \\
\hline 4 & gyilmi & relating to science & gyilmi, fenni & scientific \\
\hline 5 & medeni & relating to culture & medeni, kul'turaly & cultural \\
\cline { 3 - 5 } & & behaving in a polite and reasonable way & kul'turaly & civilized, well-behaved \\
\hline
\end{tabular}

\section{Conclusion}

The comparative analysis of languages is a key method to examine any language phenomenon. It helps to shed more light on the structural, semantic, stylistic, expressive aspects of words in a language. Today we may rely on a relatively shallow coverage of lexical phenomena in Tatar. Accordingly, the synonymy of relational adjectives is given far less attention.

As the research showed, despite the fact that Tatar relational adjectives indicate the property through the relation to the object or phenomenon, they are not strictly restricted as lexical items capable to organize synonymic rows within their semantic structures. The study covered 69 Tatar relational adjectives, organized into 17 synonymic rows, and their 133 English counterparts.

In the study the core denotation and the semantic similarity were considered as the universal features for the Tatar and English synonyms. Hence, the Tatar relational adjectives and their counterparts in English share the similar relations to time, place, activity and occupation.

According to the character of the notion denoted, the synonymic bonds within the synonymic row vary both in terms of sense relations and in number. It turned out that the similar notions are indicated differently by synonymous items in Tatar and English. There are the cases when the senses of the Tatar synonymic row are expressed by a single lexical item in English, or by several lexemes not synonymous with each other. Interestingly, the Tatar synonymic row 
dominant relational adjectives are not in a complete degree semantically identical with their counterparts in English.

Such differences in synonymic rows emphasize the specific features of Tatar and English, characterized by belonging to two mentally different national identities and cultures, following different social conditions for the existence and functioning of the languages. The knowledge of such features leads to better comprehension of any language phenomenon and the avoidance of many pitfalls for English-language learners.

We believe that such comparative studies must be promoted, because it may lead to more meticulous and cognitive approach to studying and teaching the semantic nature of languages. Moreover, it may develop a reliable theoretical framework within which an educational bilingual (Tatar-English) Dictionary of Synonyms may be made.

\section{References}

Apresyan Yu.D. (1995). Leksicheskaya semantika: sinonimicheskiye sredstva yazika. In: Shkola "Yazyki russkoy kul'tury": Izbranniye Trudy, vol. 1, (pp.472-473). Moskva: Vostochnaya literatura RAN.

Antrushina G.B. and Morozova N.N. (2001). Leksikologiya angliyskogo yazyka. Moskva: Drofa.

Bakeyeva D.H. (1985) Sopostavitel'naya fonetika angliyskogo i tatarskogo yazykov. Kazan.

Fortesque M. (2010). Similitude: A conceptual category. Acta Linguistica Hafniensia: International Journal of Linguistics, 42(2): 117-142.

Ganiyev F.A. (2005) Tatar Teleneng An'latmaly Suzlege. Kazan: Matbugat yorty.

Gatiatullina Z.Z. (1982) Sopostavitel'naya tipologiya leksicheskih sistem angliyskogo i tatarskogo yazykov: (na materiale slovoobrazovaniya). Moskva: MGPI

Kecskes I. (2008). Dueling contexts: A dynamic model of meaning. Journal of Pragmatics, 40(3): 385.

Khanbikova Sh.S. and Safiullina F.S. (1999). Sinonimnar suzlege. Kazan: Hater.

Khisamova V.N. (2004). Glagol'naya sistema tatarskogo $i$ angliyskogo yazykov: sopostavitel'niy analiz v aspekte izucheniya angliyskogo yazyka na baze rodnogo (Tatarskogo) yazyka. Kazan: Izd-vo Kazanskogo Universiteta.

Khisamova F.M. (2006). Tatar tele morfologiyase. Kazan: Magarif.

Khismatullina L.G. (2009) Sinonimiya otnositel'nyh imen prilagatel'nyh $v$ tatarskom yazyke $i$ ih ekvivalentov $v$ angliyskom yazyke (sopostavitel'noe issledovaniye) (Candidate dissertation). Kazan, Russia.

Khomenko O.E. (2006). Modelirovaniye sinonimicheskoy paradigmy s dominantoy "strah" (Candidate dissertation) Stavropol', Russia.

Lexical Semantics. (2006). In K. Malmkjær (Ed.), The Linguistics Encyclopedia. London and New-York: Routledge., pp.531-535.

Longman Exams Dictionary. (2006), Pearson: Longman.

Longman Dictionary of Contemporary English. (2009), Pearson: Longman.

Merriam-Webster Online Dictionary <http://www.merriam-webster.com/dictionary/highbrow> (accessed November 10, 2014).

Murphy M.L. (2006). Synonymy. Encyclopedia of Language and Linguistics, 2, 37-378.

New Webster's Dictionary and Thesaurus of the English Language. (1995). Danbury, CT: Lexicon Publications, Inc.

Oxford Dictionary of Synonyms and Antonyms. (1999). Oxford: University Press.

Oxford Learner's Thesaurus. A Dictionary of Synonyms, (2012). Oxford: University Press.

Safiullina F.S. (1999) Khezerge Tatar edebi tele. Leksikologiya: yugari uku yortlary studentlary ochen. Kazan: Hater.

Talmy A. (2007). Foreword. Methods in Cognitive Linguistics. Eds., Gonzalez-Marquez, M., Mittelberg, I., Coulson, S., \& Spivey, M. Amsterdam: John Benjamins Publishing Co., pp. 12-22.

Teleneng An'latmaly Suzlege (1977). vol. 1, (1979). vol. 2, (1981). vol. 3. Kazan: Tatarstan kitap neshriyaty.

Ullman S. (1984) Semantics. An Introduction to the Science of Meaning. London: Oxford.

Zakamullina M.N. (1999) Aspectual'nost' v tatatrskom i frantsuzskom yazykah: Sopostavitel'noye Issledovaniye. Kazan: Magarif 